\title{
Microfinance Services and Poverty Level of Rural Farmers of Syangja District of Nepal
}

\author{
Chandra Prasad Dhakal ${ }^{1}$ \\ Govind Nepal ${ }^{2}$
}

\author{
${ }^{1}$ Mewar University, Rajasthan, India \\ ${ }^{2}$ Tribhuvan University, Kathmandu, Nepal \\ Correspondence: Chandra Prasad Dhaka, Mewar University, Rajasthan, India,Email:chandradhakal@ hotmail.com
}

Received: November 06, $2017 \quad$ Accepted: November 11, $2017 \quad$ Online Published: November 17, 2017

\begin{abstract}
Poverty is associated with income and its distribution, which remains the core concern even today.As the data of Economy Survey 2015/2016 done by Ministry of Finance shows, that, the number of people living below poverty line has dropped to 21.6 percent in 2016 AD from 42 percent of 1995 AD. Microfinance is a form of monetary development that has first and foremost focused on alleviating poverty through giving financial services to the poor. The study was conducted with aim to identify the contribution of microfinance services to reduce the status of poverty level of rural farmers of Syangja district of Nepal. The study had used the standard poverty score card developed to measure the poverty in Nepal. The score card has ten simple questions; each question has option of response having with different score. As the national standard of Nepal, out of 100 score, who can earn more than 59 is known as non-poor whereas from the international standards it needs more than 64 to be non-poor. The result shows that Out of 385 respondents, 140 (36.4\%) were found poor and $245(63.3 \%)$ were non-poor on the national level standard of poverty. $190(49.4 \%)$ were found poor and $195(50.63 \%)$ were non-poor on the international level standard of poverty. The data of poverty line is significantly higher than the national level. Therefore, there was need of serious concern form the concerned authority of Nepal government to address the poverty issue of Syangja district.
\end{abstract}

Keywords: Farmers, Microfinance, Poverty, Rural.

\section{Introduction}

Poverty is associated with income and its distribution, which remains the core concern even today. As the data of Economy Survey 2015/2016 done by Ministry of Finance shows that, the number of people living below poverty line has dropped to 21.6 percent in 2016 AD from 42 percent of 1995 AD(Ministry of Finance, 2016, p. 109). Poverty is not specific. It is a pervasive issue and in order to alleviate poverty in the world all industrialized as well as developing countries have already taken so many initiatives. Poverty alleviation is very massive and broad issue that encompasses government policies, education, health care, rural substructure, employment prospects, provision of credit and financial services (Pollinger \& Cordero, 2007; Alderman, 2002, p. 
398). Because in this technologically advanced era the farmers must have knowledge of crop variety, weather, fertilizer etc. to maximize production and profits. Rural infrastructure is necessary to carriage the products to main agricultural markets. Provision of credit and financial services is one of the key approaches to poverty reduction that increases the confidence of poor to take initiative to start new microenterprises in developing countries. Therefore, the features of the policy have strong potential to alleviate poverty from any poor country (Banerjee, Duflo, Glennerster, \& R., 2009; Dufko, 2000, p. 397). Many international donor agencies' first agenda is to alleviate poverty. Many projects are being operated under the bilateral and unilateral contracts with other countries. Poverty reduction is the main planning instrument in improvement and there are a number of poverty reduction strategies. It is not possible to address all strategies separately in this limited study. However, this study identifies microfinance for rural agriculture as an important strategy for poverty reduction in the rural agricultural sector (Ravallion, 2007; Bardhan \& Mookherjee, 2006, p. 321). Furthermore, the focus here is on the role of microfinance services in poverty reduction in the rural agricultural sectors of Nepal.

Microfinance is a form of monetary development that has first and foremost focused on alleviating poverty through giving financial services to the poor(Akanji, 2002). Microfinance is a development tool that grants or provides financial services and products such as very small loans, savings, micro leasing, micro-insurance and money transfer to assist the very or exceptionally poor in expanding or establishing their businesses (Robinson, 2003).

Rural credit in Nepal began in 1956 with the opening of Credit cooperatives in Chitwan Valley to provide loans to the re-settlers coming from different parts of the country (Shrestha, 2009, p. 11). In 1963, the government established the Cooperative Bank, which was later converted into the Agricultural Development Bank Nepal (ADBN) in 1968.The government introduced the Cooperative Revitalization Program in 1971. It ratified the Agricultural Development Bank Nepal to run cooperatives under its control and management. ADBN launched the Small Farmers Development Program in 1975 - first as a pilot project at two sites, SakhuwaMahendranagar of Dhanush district in the Terai and Tupche of Nuwakot district in the hills (Shrestha, 2009, p. 11).

After the reinstallation of common democracy in 1990, the government appointed a seven-member National Cooperative Consultation Committee (NCCC). It also set up a National Cooperative Development Board (NCDB) constituted of 11 members to provide policy directives to the cooperatives. Similarly, the government endorsed a new Cooperative Act in 1992 to ease promotion and development of cooperatives as a vehicle for economic development in the pastoral areas. The government also underscored the role of cooperatives for outspreading credit facilities and other services to the rural people in its Eight National Plan.

The main objective of microfinance service is to provide the financial services to poor people, particularly from rural areas may help farmers to access new technologies and high yield varieties for agriculture production. Provision of financial services and products has trickle-down effects on the poor's livelihood. Microfinance for agriculture has the potential to address all factors, which are linked to poverty reduction, e.g. improved health, better education, better agricultural practices and employment opportunities (Komives, Halpern, Foster, \& Wodon, 2005). Rural microfinance products in many parts of the world are already launching innovative products especially premeditated to rural needs and poverty reduction.

\section{Objective of the Research}

The study was conducted with an aim to identify the contribution of microfinance services to reduce the status of the poverty level of rural farmers of Syangja district of Nepal.

\section{Conceptual Framework of this Research}

The study had adopted the following conceptual idea to measure the relationship between the microfinance 
activities and its impact on poverty reduction.

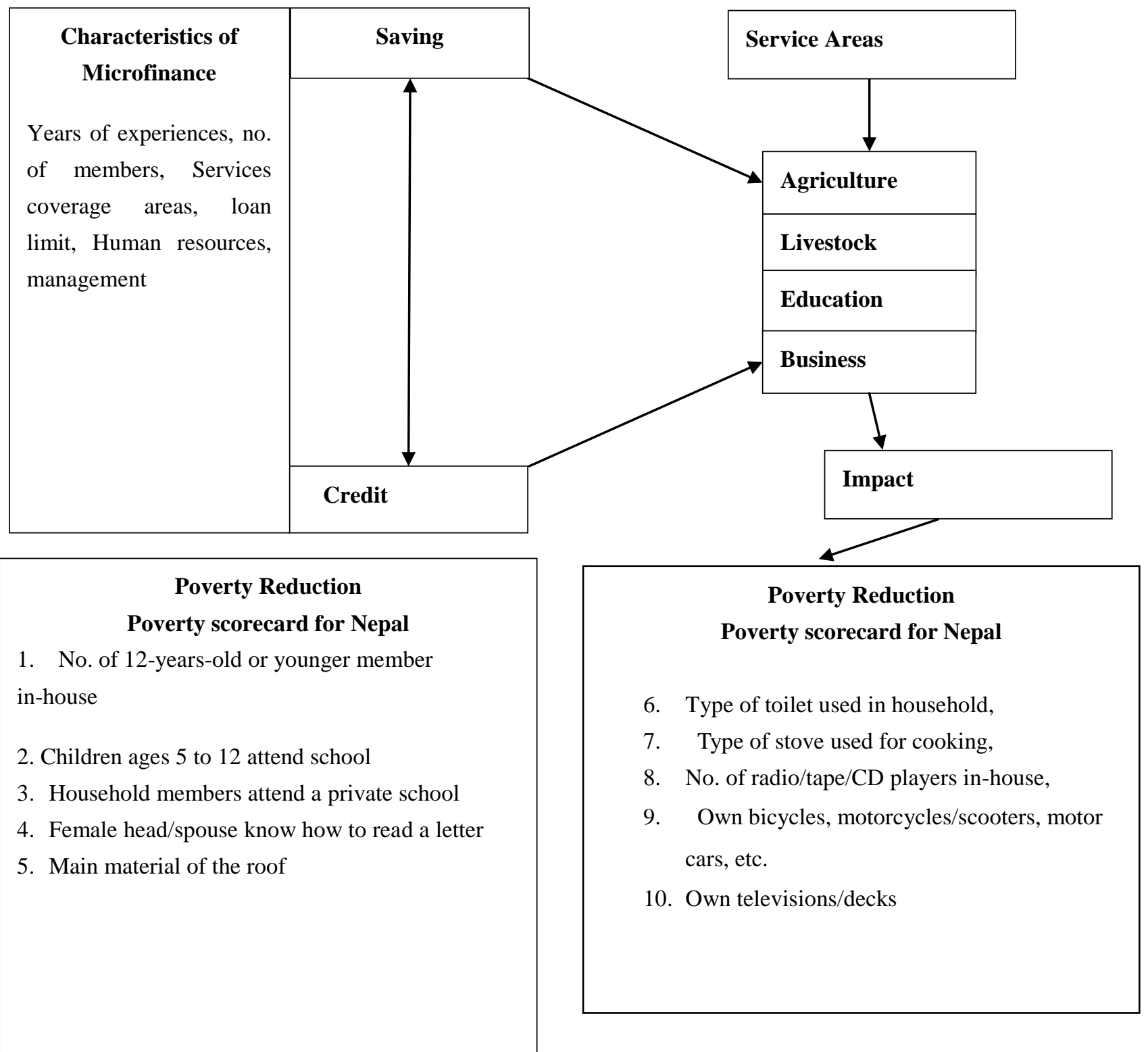

Figure 1: Conceptual Framework of the study

The conceptual framework shows that the basic characteristics of microfinance that can determine the level of financial status (saving and credit) of microfinance. As the ideology of microfinance, its main focuses on the improvement of the socio-economic status of community people. It supports in the field of agriculture, education, business promotion. Through the different economic activities, it finally contributes to poverty reduction. This study had adopted the poverty scorecard for Nepal to measure the level of poverty of small farmers. The above conceptual framework shows the core service areas of microfinance, which finally affects the poverty reduction.

\section{Materials \& Method}

The study had adopted the following methodology to conduct the study:

- Research Design:Descriptive and Explanatory design

- Sampling Design:Purposive sampling technique 
- Study area:Syangja district

- Sample size:385 (sample size calculated in 95\% confidence level and .05\% margin of error)

- Data collection tools: The study had used the standard poverty score card developed to measure the poverty in Nepal. The score card has ten simple questions; each question has an option of the response having with the different score.

- Data analysis plan: As the national standard of Nepal, out of 100 scores, who can earn more than 59 is known as non-poor whereas from the international standards it needs more than 64 to be non-poor.

\section{Result \& Discussion}

MFI schemes were initiated to meet different objectives. The most commonly mentioned objectives include poverty alleviation and improved living standards, offering to finance to the poor, women's empowerment, and the development of the business sector as a means of achieving high standards and reducing market failure. Empirical evidence and surveys give mixed results on the performance of MFIs. In some cases, tragedy stories have been reported, yet there have been success stories. In other cases, the reasons for failures or successes have not been well documented. Thus, this sub-section reports the results of the study area on the role of MFIs to reduce poverty.

The study has used a simple poverty scorecard developed for Nepal to collect the primary data from the field. The scorecard uses ten simple indicators that field workers can easily collect data and scores can be computed by hand in the field. The simple povertyscorecard is a practical way for pro-poor programs in Nepal to measure poverty rate to track changes in poverty rates over time and to target services.

\subsection{Number of household members of 12-years-old or younger}

Dependent members of that family directly affect income and expenditures of any household. During this survey, demographic data of a number of dependent members i.e. 12 years old or younger members of the household from the study area were collected.

Table 1: Number of household members of 12-years-old or younger

\begin{tabular}{|c|c|c|c|}
\hline \multicolumn{4}{|c|}{ How many household members are 12-years-old or younger? } \\
\hline Response & Value & Frequency & Percent \\
\hline Four or more & .00 & 8 & 2.1 \\
\hline Three & 6.00 & 40 & 10.4 \\
\hline Two & 12.00 & 89 & 23.1 \\
\hline One & 16.00 & 95 & 24.7 \\
\hline \multirow[t]{2}{*}{ None } & 28.00 & 153 & 39.7 \\
\hline & Total & 385 & 100.0 \\
\hline
\end{tabular}

(Source: Field Survey, 2016)

Table 1 shows the result of a number of household members of 12 years old or younger from the study area. Out of 385 respondents, 8 households $(2.1 \%)$ had four or more children of 12 years or younger. Similarly, 40 households $(10.4 \%)$ had three children of 12 years or younger. Likewise, 89 households $(23.1 \%)$ had two members of 12 years old or younger members. 95 households (24.7\%) had only one member of age 12 years or younger children. However, 153 households (39.7\%) had no members of age 12 years' old or younger children.

\section{2. Number of children ages 5 to 12 attend school}

Education to the children of any family is another important factor of a level of measuring poverty level of that household. 
Table 2: Number of children ages 5 to 12 attends school

\begin{tabular}{llll}
\hline \multicolumn{4}{l}{ How many children ages $\mathbf{5}$ to $\mathbf{1 2}$ attend school } \\
\hline Response & Value & Frequency & Percent \\
\hline Not all & .00 & 48 & 12.5 \\
\hline $\begin{array}{l}\text { No children ages } 5 \\
\text { to } 12\end{array}$ & 2.00 & 111 & 28.8 \\
\hline All & & & \\
\hline & 5.00 & 226 & 58.7 \\
\hline
\end{tabular}

(Source: Field Survey, 2016)

Table 2 shows the results of a number of children ages 5 to 12, who attend school from the households of the study area. Out of 385 surveyed households, 48 households (12.5\%) had no any children ages 5 to 12 , who were attending school. From 111 households (28.8\%) had children each age 5 to 12 , who were attending school. However, 226 households (58.7\%) had attended their all children in school. It result showed that the households were aware of education to their children. If they have the good income, it encourages them to attend their children to attend school.

\subsection{Number of household members attend a private school}

Table 3: Number of household members attends a private school

\begin{tabular}{llll}
\hline \multicolumn{1}{l}{ Do any household members attend a private school? } \\
\hline Response & Value & Frequency & Percent \\
\hline No & .00 & 240 & 62.3 \\
\hline Yes & 8.00 & 145 & 37.7 \\
\hline & Total & 385 & 100.0 \\
\hline
\end{tabular}

(Source: Field Survey, 2016)

Table 3 shows the result of a number of household members who attend a private school. From the surveyed data, out of 385 respondents, 240 households (62.3\%) did not attend private school. However, 145 households $(37.7 \%)$ attended private school. In the context of Nepal, those who have the sound economic status they attend their children in private school.

5.4. Female head/spouse know how to read a letter

Table 4: female head/spouse know how to read a letter

\begin{tabular}{|c|c|c|c|}
\hline \multicolumn{4}{|c|}{ Does the female head/spouse know how to read a letter? } \\
\hline Response & Value & Frequency & Percent \\
\hline No & .00 & 68 & 17.7 \\
\hline $\begin{array}{ll}\text { No } & \text { female } \\
\text { head/spouse } & \end{array}$ & 5.00 & 14 & 3.6 \\
\hline \multirow[t]{2}{*}{ Yes } & 8.00 & 303 & 78.7 \\
\hline & Total & 385 & 100.0 \\
\hline
\end{tabular}

(Source: Field Survey, 2016)

Table 4 shows the results of literacy rate of female head of surveyed households. To measure the literacy rate of those female heads they were asked whether they could read a letter or not. In the results, 0.00 indicates that they cannot read a letter, 5.00 indicates that there is no female head and 8.00 indicates that they can read a letter. Thus, results were such that out of 385 respondents, 68 (17.7\%) female head could not read a letter. 14 (3.6\%) 
surveyed households had no female head. However, 303 (78.7\%) female heads could read a letter. It shows that better economic status promotes to education.

\subsection{Main material of the roof}

Table 5: Main material of the roof

\begin{tabular}{llll}
\hline What is the main material of the roof? & & & \\
\hline Response & Value & Frequency & Percent \\
\hline Straw/thatch, wood/planks, & .00 & 15 & 3.9 \\
\hline Tiles/slate & 4.00 & 100 & 26.0 \\
\hline Galvanized iron, or concrete/cement & 10.00 & 270 & 70.1 \\
\hline & Total & 385 & 100.0 \\
\hline
\end{tabular}

(Source: Field Survey, 2016)

Table 5 shows the result of materials used in the roof of houses. Here, 0.00 indicates straw/thatch, 4.00 indicate titles/slate and 10.00 indicate galvanized iron/concrete cement. Out of 385 respondents, 15 (3.9\%) reported that roofs of their houses were made of straw/thatch. $100(26 \%)$ respondents reported that titles/slate was used on the roof. Similarly, $270(70.1 \%)$ respondents reported that their roof of houses was made up of either galvanized iron or concrete. It proves that they have sound economic status.

\subsection{Type of toilet is used by household}

Table 6: Type of toilet is used by household

\begin{tabular}{llll}
\hline What type of toilet is used in your household? & & Percent \\
\hline Response & Value & Frequency & 5.5 \\
\hline No toilet & .00 & 21 & 94.5 \\
\hline Household non-flush & 7.00 & 364 & 100.0 \\
\hline & Total & 385 & \\
\hline
\end{tabular}

(Source: Field Survey, 2016)

Another factor of measuring economic status of households is the type of toilet they use. Table 6 shows the result of the type of toilets they use. Out of 385 respondents, 21 (5.5\%) respondents reported that they did not have the toilet. However, 364 (94.5\%) respondents reported that they had either non-flush or flush toilet. It also proves that they have better economic status.

\subsection{Type of stove used in household for cooking}

Table 7: Type of stove used in household for cooking

\begin{tabular}{llll}
\hline What type of stove does your household mainly use for cooking? & Value & Frequency & Percent \\
\hline Response & .00 & 179 & 46.5 \\
\hline Open fireplace, other, or no data & 5.00 & 206 & 53.5 \\
\hline Mud stove, smokeless stove, or kerosene/gas stove & Total & 385 & 100.0 \\
\hline
\end{tabular}

(Source: Field Survey, 2016)

Type of stoves used in household for cooking is another factor to measure the economic status of any family. Table 7 shows the result of a type of stoves used in household for cooking. In the result, 0.00 indicates that they use an open fireplace for cooking and 5.00 indicates that they use mud stove, smokeless stove, kerosene stove or gas stoves. Out of 385 respondents, 179 (46.5\%) used an open fireplace for cooking. 206 (53.5\%) used mud stove, smokeless stove, kerosene stove or gas stove. 


\subsection{Number of radio/tape/CD players available in house}

Table 8: Number of radio/tape/CD players available in house

\begin{tabular}{llll}
\hline \multicolumn{4}{l}{ How many radio/tape/CD players do the household own? } \\
\hline Response & Value & Frequency & Percent \\
\hline None & .00 & 132 & 34.3 \\
\hline One & 6.00 & 194 & 50.4 \\
\hline Two or more & 13.00 & 59 & 15.3 \\
\hline & Total & 385 & 100.0 \\
\hline
\end{tabular}

(Source: Field Survey, 2016)

Table 8 is about a result of a number of radio/tape/CD players available in-house. In the result, 0.00 indicates that they do not own any sort of media players like radio, tape or CD players. 6.00 indicates that they have only one of them and 13.00 indicates that they own two or more. Out of 385 respondents, 132 (34.3\%) reported that they owned none of them. 194 (50.4\%) reported that they owned only one of them. Similarly, 59 (15.3\%) reported that they owned two or more such types of media players. It showed that majority of them owned media players.

5.9. Household own any bicycles, motorcycles/scooters, motor cars, etc

Table 9: Household own any bicycles, motorcycles/scooters, motor cars, etc

\begin{tabular}{llll}
\hline \multicolumn{1}{l}{ Does the household own any bicycles, motorcycles/scooters, motor cars, etc } & \\
\hline Response & Value & Frequency & Percent \\
\hline No & .00 & 314 & 81.6 \\
\hline Yes & 5.00 & 71 & 18.4 \\
\hline & Total & 385 & 100.0 \\
\hline
\end{tabular}

(Source: Field Survey, 2016)

Availability of means of transportation is another factor to measure economic status of any household. Respondents were asked whether they owned any bicycle, motorcycle, scooter or motorcar. Out of 385 respondents, $314(81.6 \%)$ reported that they did not own any sort of means of transportation and only $71(18.4 \%)$ reported that they owned such type of means of transportation.

5.10. Household own any televisions/decks

Table 10: Household own any televisions/decks

\section{Does the household own any televisions/decks?}

\begin{tabular}{llll}
\hline Response & Value & Frequency & Percent \\
\hline No & .00 & 64 & 16.6 \\
\hline Yes & 11.00 & 321 & 83.4 \\
\hline & Total & 385 & 100.0 \\
\hline
\end{tabular}

(Source: Field Survey, 2016)

Table 10 shows the data of household survey from study area on whether they own television or deck at home. Out of 385 respondents, $64(16.6 \%)$ reported that they did not own any television or deck. On the other hand, $321(83.4 \%)$ respondents reported that they owned either television or deck.

\subsection{Poverty likelihood (\%), legacy-definition lines}

The simple poverty scorecard is an easy-to-use tool that local pro-poor development programs in Nepal can use for targeting, for monitoring their participants' poverty rates, and for tracking changes in participants' poverty 
rates over time. Field agents visit participants in their homes and ask 10 simple, objective questions to know the poverty status. The poverty likelihood legacy definition lines define the level poverty because of total score obtained from the 10-poverty scorecard. From the below table, the household who can score more than 59 are known as non-poor from the national standard whereas more than 64 scores is needed for the international standard to be non-poor. The below data has reported the poor and non-poor household from both national and international standard.

Table 11: Poverty likelihood (\%), legacy-definition lines

\begin{tabular}{|c|c|c|c|c|}
\hline \multicolumn{5}{|c|}{ Poverty likelihood $(\%)$, legacy-definition lines } \\
\hline Score & National $100 \%$ & Intl. 2005 PPP \$1.25 & Frequency & Percent \\
\hline $15-19$ & 46.5 & 75.5 & 1 & .3 \\
\hline $20-24$ & 36.3 & 72.2 & 2 & .5 \\
\hline $25-29$ & 25.9 & 65.9 & 3 & .8 \\
\hline $30-34$ & 16.6 & 55.4 & 2 & .5 \\
\hline $35-39$ & 8.7 & 42.9 & 10 & 2.6 \\
\hline $40-44$ & 5.7 & 28.4 & 5 & 1.3 \\
\hline $45-49$ & 1.2 & 16.2 & 20 & 5.2 \\
\hline $50-54$ & 0.5 & 9.2 & 44 & 11.4 \\
\hline $55-59$ & 0.2 & 2.7 & 53 & 13.8 \\
\hline $60-64$ & 0.0 & 1.7 & 50 & 13.0 \\
\hline Above 65 & 0.0 & 0.0 & 195 & 50.6 \\
\hline Total & & & 385 & 100.0 \\
\hline
\end{tabular}

(Source: Field Survey, 2016)

Table 11 shows the results of poverty scores of surveyed data from the study area. The above scores are based on Mark Schreiner's "A Simple Poverty Scorecard for Nepal" (2013, p. 5). Out of 385 respondents, only 1 (0.3\%) scored $15-19$, that is $46.5 \%$ below the poverty line on the national level and $75.5 \%$ on the international level. Similarly, 2 respondents $(0.5 \%)$ scored $20-24$, i.e. $36.3 \%$ below the poverty line on the national level and $72.2 \%$ on the international level. $3(0.8 \%)$ scored $25-29$, i.e. $25.9 \%$ below the poverty line on the national level and $65.9 \%$ on the international level. Another 2 respondents $(0.5 \%)$ scored 30-34, i.e. $16.6 \%$ below the poverty line on the national level and $55.4 \%$ on the international level. Likewise, 10 respondents (2.6\%) scored 35-39, i.e. $8.7 \%$ below the poverty line on the national level and $42.9 \%$ on the international level. 5 respondents $(1.3 \%)$ scored $40-44$, i.e. $5.7 \%$ below the poverty line on the national level and $28.4 \%$ on the international level. Other 20 respondents $(5.2 \%)$ scored $45-49$, i.e. $1.2 \%$ below the poverty line on the national level and $16.2 \%$ on the international level. Similarly, 44 respondents $(11.4 \%)$ scored $50-54$, i.e. $0.5 \%$ below the poverty line on the national level and $9.2 \%$ on the international level. 53 respondents (13.8\%) scored 55-59, i.e. $0.2 \%$ below the poverty line on the national level and $2.7 \%$ on the international level. 50 respondents (13\%) scored 60-64, i.e. $0 \%$ below the poverty line on the national level and $1.7 \%$ on the international level. Out of 385 respondents, 195 $(50.6 \%)$ were found above the poverty line on both national and international level. It proves that microfinance institutions are helping on poverty reduction in Nepal.

\subsection{National standard of poverty}

Country Poverty Analysis (Detailed) Nepal (ADB)draws mainly on the National Living Standards Surveys (NLSS), which was first conducted in 1996, and carried out again in 2004 and 2011.The NLSS estimates the 
national poverty line following the cost of basic needs approach, which is the expenditure value of local currency required to fulfill both food and non-food basic needs(p. 2).

Using the national poverty line, poverty incidence has been falling at an accelerated pace from $41.8 \%$ to $30.9 \%$ between 1996 and 2004 and further to $25.2 \%$ of the overall population in 2011. This remarkable decline occurred in the backdrop of a significant increase in the national poverty line from NRs7, 696 per capita per year in 2004 to NRs19,261 per capita per year in 2011 to account for a higher quality consumption pattern(ADB, p. 3). Using international poverty line of $\$ 1.25$ per day, the incidence of poverty has declined steadily from $68.0 \%$ in 1996 to $53.1 \%$ in 2004 and $24.8 \%$ in 2011 . Poverty incidence at $\$ 2$ per day has similarly declined from $89.0 \%$ in 1996 to $77.3 \%$ in 2004 and $57.3 \%$ in 2011(ADB, p. 3). Despite the remarkable decline in overall poverty level, poverty in rural Nepal is still higher than urban Nepal, even though rural poverty is declining at a faster pace than urban poverty. While urban poverty fell from " $21.6 \%$ in 1996 to $10.0 \%$ in 2004 , it again rose to $15.5 \%$ in 2011 . On the other hand, rural poverty has declined continuously from $43.3 \%$ to $35.0 \%$ and to $27.4 \%$ between 1996, 2004 and 2011"(ADB, p. 2).

Table 12: National standard of poverty

\begin{tabular}{llll}
\hline National standard of poverty & & \\
\hline \multirow{2}{*}{ Valid } & & Frequency & Percent \\
\cline { 2 - 4 } & Poor & 140 & 36.4 \\
\cline { 2 - 4 } & Non poor & 245 & 63.6 \\
\cline { 2 - 4 } & Total & 385 & 100.0 \\
\hline
\end{tabular}

(Source: Field survey 2016)

Table 12 shows the results of poor and non-poor based on a national level standard of poverty from the study area. Out of 385 respondents, 140 (36.4\%) were found poor and 245 (63.3\%) were non-poor on the national level standard of poverty.

\subsection{International standard of poverty \$1.25 per/day 2005 PPP}

Table 13: International standard of poverty $\$ 1.25$ per/day 2005 PPP

\begin{tabular}{llll}
\hline \multicolumn{2}{l}{ International standard of poverty $\$ \mathbf{\$ 1 . 2 5}$ per/day } & & \\
\hline \multirow{2}{*}{ Valid } & & Frequency & Percent \\
\cline { 2 - 4 } & Poor & 190 & 49.4 \\
\cline { 2 - 4 } & Non poor & 195 & 50.6 \\
\cline { 2 - 4 } & Total & 385 & 100.0 \\
\hline
\end{tabular}

(Source: Field Survey, 2016)

Table 13 shows the results of poor and non-poor based on an international level standard of poverty from the study area. Out of 385 respondents, 190 (49.4\%) were found poor and 195 (50.63\%) were non-poor on the international level standard of poverty. Thus, it clearly proves that microfinance institutions are helping on poverty reduction.

The study had collected some opinion and experience of rural farmers regarding the contribution of microfinance services to change their socio-economic life style. The interview was conducted at community level and responses are analyzed in narrative form as a case study to logically support the findings of quantitative data. The responses are as bellows:

The level of poverty is influenced by the economic status of the household. The study also conducted the face-to-face interview with key informants to know their experience about the impact of MFI in poverty 
reduction. Mrs. Shanti Gurung, the resident of Phedikhola, Syangja shared her experience about the improvement of her poverty status after joining the microfinance program. She was doing Livestock (Buffalo) farming. Phedikhola is emerging market areas. There are some hotels and other shopping Centre. Mrs. Gurung was searching some self-employment services, but no ideas what to do and no money in her hand also so she was in tension. One day, one of her neighbor who was doing tea shop in market suggested her to do the livestock farming to produce milk for market. There was no adequate milk production as the need of market. Then, she discussed with her family and became ready for business. She went in local Women Group, and in their recommendation, microfinance gave her NPR. 1 Lakh for 2 years then she purchased 2 buffalos and started milk supply in the market. Gradually, she collected 5 buffalos and paid the loan of microfinance also. She became the self-employee. She had improved her economic status and social goodwill also. She was doing her business very honestly. She was providing very original milk so everybody came to her for milk. Customers respected her and living the prestigious life in society. Her husband also came back from India and joined in her business and then they were planning to start goat farming also very soon.

\section{Conclusion}

From the study of Microfinance service in Syangja district, it has covered 5 to 58 VDCs during the last 20 years of service in Syangja district.The manager of microfinance reported that 50\% to 92\% with mean $71.5 \%$ customers were benefited from loans facility of microfinance. Basically, microfinance has provided loan for farming, petty trade, and small-scale manufacturing. Microfinance institutions are accepted as the institution of the local community; it is for the local development and contribution for the poor of poor so beneficiaries are very conscious to repay their loan in time with an accepted interest rate.

Microfinance service has discouraged the loan borrowing from the local landlord that has protected from the economic exploitation. With the improvement in economic status; social status of people is also increased; self-confidence and self-esteem are increased. Life style is changed with the use of modern technology to make the day-to-day life easy. The communication and leadership skill of rural farmer was improved; they could raise their voice in front of mass or concerned authority. Microfinance has significantly contributed to improving in access to education, health services, decision-making, and other social involvement. Women are aware on their rights of the decision on household assets. They are also become capable to form the group and its mobilization for the development of the community.

It was found that annual mean income after joining microfinance is increased by $30.23 \%$ and expenditure is increased by $31.30 \%$ which indicates the improvement in poverty level of rural farmers. The data of poverty line among the beneficiaries of Microfinance of Syanga district is significantly higher than the national level. Therefore, there was need of serious concern form the concerned authority of Nepal government to address the poverty issue of Syangja district.

\section{Recommendation}

- Future research can access the impact of microfinance services on poverty reduction by using the 'Before and after' study design in another region of Nepal.

- There is need of loan management and utilization training to the customers before providing a loan so that they can use the loan in the productive sector for the long-term benefit.

\section{References}

ADB. (n.d.). Country Poverty Analysis (Detailed) Nepal. Retrieved December 29, 2016, from https://www.adb.org/sites/default/files/linked-documents/cps-nep-2013-2017-pa-detailed.pdf 
Akanji, O. (2002). Microfinance as Strategy for Poverty Reduction. Nigeria Research Department: Economic and Financial Review, 39 (4), 43-56.

Alderman, H. (2002). Do local officials know something we don't? Decentralization of targeted transfers in Albania. Journal of Public Economics, 83, 375-404.

Banerjee, A., Duflo, E., Glennerster, \& R., K. C. (2009). The miracle of microfinance? Evidence from a randomized evaluation. Massachusetts Institute of Technology.

Bardhan, P., \& Mookherjee, D. (2006). Pro-poor targeting and accountability of local governments in West Bengal. Journal of Development Economics, 79, 303-327.

Dufko, E. (2000). Child Health and Household Resources in South Africa: Evidence from the Old Age Pension Program. American Economic Review, 90 (2), 393-398.

Komives, K., Halpern, J., Foster, V., \& Wodon, Q. (2005). Water, Electricity and the Por: Who Benefits from Utility Subsidies. World Bank.

Ministry of Finance. (2016). Economic Survey: Fiscal Year 2015/16. Kathmandu, Nepal: Government of Nepal.

Pollinger, O., \& Cordero, G. (2007). The Question of Sustainability for Microfinance Institutions. Journal of Small Business Management, 45 (1), 23-41.

Ravallion, M. (2007). How Relevant is Targeting to the Success of an Antipoverty Program?

Robinson, M. (2003). The microfinance revolution: Sustainable finance for the poor. Washington D.C.: World Bank.

Schreiner, M. (2013, October 2). A Simple Poverty Scorecard for Nepal.

Shrestha, S. M. (2009). State of Microfinance in Nepal. Kathmandu: Institute of Microfinance.

\section{Copyrights}

Copyright for this article is retained by the author(s), with first publication rights granted to the journal. 